\title{
The Effect of Mall Strategy Integrated with Padlet Towards Students' Reading Comprehension
}

\author{
I Gede Yoga Prastya
}

Language Education Program, English Eduacation Program, Universitas Pendidikan Ganesha, Indonesia

\section{Keywords:}

reading;

MALL;

Padlet.

\section{ABSTRACT}

Abstract: The research aimed at investigating the significant difference on students' reading comprehension between students taught using Mobile Assisted Language Learning (MALL) strategy integrated with Padlet and students taught using conventional teaching strategy. This research was quasi-experimental utilizing post-test only control group design. The population of this research was tenth-grade students in SMA Negeri 4 Singaraja. The sample of this research were 73 students consisting of 35 students from $X$ BB 1 as experimental group and 38 students from $B B 2$ as control group. The sample were chosen using cluster random sampling technique. The data collection in both groups were done through post-test. The obtained data were analyzed using descriptive and inferential statistical analysis. The result of descriptive statistics analysis reveals that the mean score for experimental group is higher than control group (78.03 > 73.39). Furthermore, the result of inferential statistics analysis through $t$-test shows that the significant value of $t_{\text {observe }}$ is higher than $t_{\text {critical value, which is } 2.270>}$ 1.666 ( $d f=71, \alpha=0.05)$. Thus, it indicates that there is a significant difference on students' reading comprehension between students taught using Mobile Assisted Language Learning (MALL) strategy integrated with Padlet and students taught using conventional teaching strategy.

Correspondance address:

E-mail: gedeyoga974@gmail.com (I Gede Yoga Prastya)

\section{Introduction}

Reading has been an importance skill in learning English as foreign language. In EFL learning context, reading becomes necessary to be mastered by students (Alshumaimeri, 2011; Asmawati, 2015; Khaki, 2014). Since it is a foundation for the students to learn a language (Takaloo \& Ahmadi, 2017). It is not an easy activity to do, because it requires comprehension to construct meaning from a written text (Mutia, Syafar, \& Dewi, 2016). Through a good reading comprehension the students can get information that they need. Therefore, it becomes an importance skill for the students to construct meaning from a reading text.

However, teaching strategy used by teacher has an important role in helping students to have good reading comprehension. As the result of prelimenary observation showed that the strategy used by the teacher focused on teacher-centered. It can be categorized as conventional teaching strategy, because teacher-centered is a mode of conventional strategy (Liu and long, 2014). It makes the role of teacher in the learning process becomes the main source of knowledge (Miller, Merrill, and Shamatov, 2018). Since the main source of knowledge is a teacher, it limits the information that students receive related to material (Liu and long, 2014). Besides, the communication and discussion only can be done in the classroom by face to face (Liu and long, 
2014). It will be hard for both teacher and students to transfer or receive a material if they cannot attend in the class.

On the other hand, nowadays students tend to use their smartphone rather than hold and read a written book (Kavlu, 2015). He also added that instead of sharing their understanding toward a reading passage, they prefer to share photos. As students who were born between 1995 until the early month of 2020 are categorized as generation Z (Veluchamy, Bharadwaj, Vignesh, \& Sharma, 2016).

Gen Z also well known as "Digital Native" (Singh, 2014). Technology is the identity of generation $z$ because they born and live in the social web (Singh and Dangmei, 2015). As students who were born into the world that facing that environment, they will easily adapt and know the widespread of technology such as electronic devices, digital technology, and internet. Since generation $\mathrm{Z}$ is more familiar with new technology and has digital fluency (Cakir, 2016). Thus, it come to a possible solution that teacher should use a teaching strategy that can be integrated with mobile phone.

It is important to integrate technology and internet in learning process (Liu \& Long, 2014). Moreover, the development of language learning strategies require the teacher to prepare and encourage students (Dashtestani, 2013). A new strategy in language learning that involves the role of mobile phone in learning process is called as MALL. It is a type of mobile learning (m-learning) and a subset of computer assisted language learning (CALL) (Kealey, 2014). However, MALL and CALL are not the same viewed from personal use and portability (Widiana, Santosa, \& Myartawan, 2018).

According to Khubyari \& Narafshan (2016), MALL is defined as a teaching and learning strategy integrated with mobile phones or other handheld devices that uses wireless connectivity to link all the participants. Kim (2014) viewed MALL as a strategy in language teaching that has a great potential in providing an authentic experiences whether it it is inside or outside of the classroom. The students also can learn at anytime with no limited hours as the learn in classroom context of learning (Bezircilioğlu, 2016). It is line with Hazaea and Alzubi (2018) state that MALL can be integrated with learning activities to promote language skills and focuse on student-centered approach.

Widiana, Santosa, \& Myartawan (2018) caracterize MALL as wireless, personal, networking, and ubiquitous. It also deals with the use of mobile devices such as PDAs, phones, and other handheld devices (Miangah \& Nezarat, 2012). In language learning context, there are five features of MALL that support the learning circumtances such as access to authentic materials, audio and video recording, access to internet, texting, and enhance learners' comunicative skills (Sa'aleek, 2014).

Numerous studies had been conducted which related to the involvement of mobile technology in learning English setting, especially on students' reading comprehension. Hazaea and Alzubi (2016) investigated the efficiency of using mobile technology in teaching English as a Foreign Language (EFL) reading classroom of 30 male students at Preparatory Year, Najran University. The result revealed that using mobile WhatsApp, online and offline dictionaries, mobile camera, online resources, and mobile memo improved the participants' code breaking practices and text participation practices. Naderi \& Akrami (2018) investigated the effect of instruction through telegram groups on the learners' reading comprehension. The result showed that that instruction through telegram groups has a significant effect on the Intermediate students' reading comprehension ability.

Since mobile assisted language learning has a great potential in language learning, there are many applications that can be integrated with this teaching strategy, and Padlet is one of them. Padlet is an online wall web-based where the students can share their ideas through a virtual post (Shield, 2014 as cited in Haris, Yunus, \& Badusah, 2017). Siu and Zhou (2017) viewed Padlet as an online virtual board where teacher and students can learn collaboratively, reflect to each other by sharing links and pictures as the source of information for related material. It can be accessed by using any type of electronic devices that are connected to internet (Padlet; Baida, 2014 as cited in Putri and Umam, 2018). 
Numerous studies had been conducted which related to the use of Padlet in EFL setting. Manowong (2017) explore EFL learners' Englih reading and learning experiences while using online tools, Padlet. The result indicated that the online tool (Padlet) was succesfully enhanced students' experience when reading English text. Nurviyani (2018) investigated the effectiveness of padlet application as an instructional media in fostering college students' critical reading skill in higher education. The result showed that the implementation of padlet application in fostering students' critical reading skill was effective with the result revealed significant difference.

Consequently, the current research intended to investigate whether or not there is a significant difference between students who taught using MALL strategy integrated with Padlet and students who taught using conventional teaching strategy in tenth grade-students in SMA N 4 Singaraja.

\section{Methods}

The research adopted quasi-experiment utilizing post-test only control group design. The participants of this research were 73 tenth-grade students in SMA N 4 Singaraja. In determining the samples of the research, cluster random sampling was employed to do so. There were two classes chosen as the sample, in which one class for experimental group and another one for control group. Lottery was applied to determine the group for the research. There were three instruments utilized to collect the data for the current research. First was instrument for collecting data, it was post-test used for both experimental and control group. Next was instrument for supportive data, it was teaching scenario. The design of learning activities of teaching scenarios in both groups were different. The other one was instrument for try-out.

Before administering the post-test to experimental and control group, validity and reliability of the instrument would be checked first. The content validity was checked by two expert judgements, then tried-out to a class out of samples. The score of try-out test was utilized to check the empirical validity. As the result, there were 30 items left and 10 items were dropped out. KR-20 (Kuder-Richardson) formula. KR-20 was used to measured reliability of the instrument. The result of calculation was 0.83 which indicated reliable.

After the instrument (post-test) was being tested in both samples, the students' post-test score were analyzed descriptively and inferentially by using Statistical Package for Social Science (SPSS) 24.0 version. The descriptive statistical analysis included the calculation of mean score, median, mode, range, standard deviation and variance of the experimental and control group. Meanwhile, the inferential statistical analysis included normality test, homogeneity test, and hypothesis testing.

\section{Results and Discussion}

Table 1 Result of Descriptive Statistics Analysis

\begin{tabular}{cccc}
\hline \multirow{2}{*}{ No. } & Statistics & \multicolumn{2}{c}{ Group } \\
\cline { 3 - 4 } & & Experiment & Control \\
\hline $\mathbf{1}$ & Mean & 78.06 & 73.39 \\
\hline $\mathbf{2}$ & Median & 77 & 73 \\
\hline $\mathbf{3}$ & Mode & 70 & 80 \\
\hline $\mathbf{4}$ & Std. Deviation & 8.75 & 8.78 \\
\hline $\mathbf{5}$ & Variance & 76.59 & 77.11 \\
\hline $\mathbf{6}$ & Range & 30 & 30 \\
\hline $\mathbf{7}$ & Minumum & 63 & 60 \\
\hline $\mathbf{8}$ & Maximum & 93 & 90 \\
\hline
\end{tabular}


Based on the result of descriptive statistics analysis in Table 1, there was a significant difference on students' reading comprehension between both groups. It was shown by the mean score of experimental group which was taught using MALL strategy integrated with Padlet was higher than the mean score of control group that was thaught using conventional strategy, which was $78.06>73.39$.

Inferential statistical analysis utilizes to calculate normal distribution and homogeneity of the data. The result of normality test and homogeneity test can be seen in table 2 and table 3 .

Tabel 2 The Result of Normality Test Tests of Normality

\begin{tabular}{|c|c|c|c|c|c|c|c|}
\hline \multirow[b]{2}{*}{ Group } & & \multicolumn{3}{|c|}{ Kolmogorov-Smirnov ${ }^{\mathrm{a}}$} & \multicolumn{3}{|c|}{ Shapiro-Wilk } \\
\hline & & Statistic & df & Sig. & Statistic & df & Sig. \\
\hline \multirow[t]{2}{*}{ Score } & $\begin{array}{l}\text { Experime } \\
\mathrm{nt}\end{array}$ & .118 & 35 & $.200^{*}$ & .953 & 35 & .144 \\
\hline & Control & .133 & 38 & .088 & .944 & 38 & .055 \\
\hline
\end{tabular}

*. This is a lower bound of the true significance.

a. Lilliefors Significance Correction

Test of Homogeneity of Variance

Based on the result of the normality test showed in Table 2, the two groups had higher significant value than 0.05 . The significant value of experimental group was 0.200 , and the significant value of control group was 0.088 . Thus, it could be concluded that both groups had normal distribution.

Table 3 The Result of Homogeneity Test

\begin{tabular}{cll|l|l|l} 
& \multicolumn{2}{c}{$\begin{array}{l}\text { Levene } \\
\text { Statistic }\end{array}$} & df1 & df2 & Sig. \\
\hline Score & Based on Mean & .000 & 1 & 71 & .992 \\
\cline { 2 - 6 } & Based on Median & .000 & 1 & 71 & .999 \\
\cline { 2 - 6 } $\begin{array}{l}\text { Based on Median and } \\
\text { with adjusted df }\end{array}$ & 1 & 70.996 & .999 \\
$\begin{array}{l}\text { Based on trimmed } \\
\text { mean }\end{array}$ & 1 & 71 & .985 \\
\hline
\end{tabular}

The result of homogeneity test above showed that the significant value of both groups was 0.992. It was higher than 0.05 . Hence, based on that result both groups were homogeneous.

After the data were normally distributed and homogeneous, then independent sample test can be conducted in purpose to the hypothesis $\left(\mathrm{H}_{0}\right)$. The result of independent $t$-test can be seen in table 4.

Table 4 The Result of Independent t-test

\begin{tabular}{|c|c|c|c|c|c|c|c|c|c|c|}
\hline \multicolumn{11}{|c|}{ Independent Samples Test } \\
\hline & & \multicolumn{2}{|c|}{$\begin{array}{l}\text { Levene's Test for Equality of } \\
\text { Variances }\end{array}$} & \multicolumn{7}{|c|}{ t-test for Equality of Means } \\
\hline & & \multirow[b]{2}{*}{$\mathrm{F}$} & \multirow[b]{2}{*}{ Sig. } & \multirow[b]{2}{*}{$t$} & \multirow[b]{2}{*}{ df } & \multirow[b]{2}{*}{ Sig. (2-tailed) } & \multirow{2}{*}{$\begin{array}{c}\text { Mean } \\
\text { Difference }\end{array}$} & \multirow{2}{*}{$\begin{array}{l}\text { Std. Error } \\
\text { Difference }\end{array}$} & \multicolumn{2}{|c|}{$\begin{array}{l}95 \% \text { Confidence Interval of the } \\
\text { Difference }\end{array}$} \\
\hline & & & & & & & & & Lower & Upper \\
\hline \multirow[t]{2}{*}{ Score } & $\begin{array}{l}\text { Equal variances } \\
\text { assumed }\end{array}$ &, 000 &, 992 & 2,270 & 71 & .026 & 4,6624 & 2,0539 & .5670 & 8,7578 \\
\hline & $\begin{array}{l}\text { Equal variances not } \\
\text { assumed }\end{array}$ & & & 2,270 & 70,548 & ,026 & 4,6624 & 2,0536 &, 5671 & 8,7577 \\
\hline
\end{tabular}


Based on the result of the t-test in Table 4.4, it showed that the significant value of $t_{\text {observed }}$ was 2.270 , which was higher than $t_{\text {critical value }}$ which is 1.666 ( $\left.d f=71, \alpha=0.05\right)$. It revealed that the null hypothesis $\left(\mathrm{H}_{0}\right)$ was rejected. Thus, there is any significant difference on students' reading comprehension between students taught using MALL strategy integrated with Padlet and students taught using conventional strategy.

Along the process of researching in both experimental and control group, there were some differences found in that process, such as motivation, participation, and learning environment. The students in control group seemed like demotivated during the process of giving treatment. Since the form of story was not interesting for them and could not stimulate them to learn, there were some students who felt sleepy, and some students were hard to understand what was the story about. On the other hand, the students who were taught by using the involvement of mobile technology integrated with Padlet seemed to be happy and enthusiastic. The students were easily adapted with the learning strategy and did not need much time to teach them about how to learn with Padlet. As students who were born into the world that facing digital environment, they would be easy to adapt and know the widespread of technology such as electronic devices, digital technology, and internet (Singh and Dangmei, 2015). This is in line with the finding from Fageeh (2013) and Miller and Cuevas (2017) which stated that the motivation of students in experimental group were enhanced by integrating mobile learning.

The motivation of students influenced their participation along the process of treatment. Since the students in control group were demotivated with to learn, they were not actively participated. In contrary, the students in experimental group were actively participated on digital wall designed by the teacher in Padlet. The students could learn collaboratively in Padlet (Putri and Umam, 2018). They also could share any forms of file, such as documents, photos, videos, or even link (Shield, 2014 as cited in Haris, Yunus, \& Badusah , 2017). It confirmed by the finding from Jabbour (2014) and Kaliisa and Picard (2017) who stated that the involvement of mobile technology increased participation of the students. This is in line with the finding from Manowong (2017) who stated that the active participation of students in English reading activities was encouraged by the use of Padlet.

The motivation and participation of students affected the class situation. The students in control group were treated by using conventional teaching strategy which was teacher and book as the main source of knowledge (Miller, Merrill, \& Shamatov, 2018). It limited chance of the students to participate in a discussion. That kind of situation created a learning environment which was boring for the students. The different learning environment happened in experimental group. The students were enthusiastic and active along the process of treatment. Besides of learning collaboratively in the digital wall, students could also learn independently. They could find additional information about the material from other sources through the internet. Since personal and networking are the characteristics of MALL strategy (Widiana, Santosa, \& Myartawan, 2018). It created an interesting learning environment. It is in line with the finding from Sulisworo and Toifur (2016), and Miller and Ceuvas (2017) which stated that the use of mobile technology shifted learning environment into more personalized and interactive, in which made students felt enthusiastic and eager to learn.

\section{Conclusion}

This research concludes that there was a significant different on students' reading comprehension between students taught using MALL strategy integrated with Padlet and students taught using conventional teaching strategy in tenth grade students in SMA N 4 Singaraja. It is supported by the result of descriptive statistics analysis and inferential statistics analysis. The mean score of the experimental group was higher than the control group. Based on the result of descriptive statistics analysis revealed that the mean score of experimental group was 78.06, while 
73.39 was the mean score of the control group. It is strengthened by inferential analysis, in which the result showed $t_{o b s}$ (2.270) was higher than $t_{c v}(1.666)$. Hence, the conclusion derives to $a$ rejection of null hypothesis which states that "there is a significant difference on students' reading comprehension between students taught using Mobile Assisted Language Learning (MALL) integrated with Padlet and students taught using conventional teaching strategy in tenth grade students in SMA N 4 Singaraja."

\section{References}

Ahmadi, M., \& Takaloo, N. (2017). The Effect of Learners' Motivation on Their Reading Comprehension Skill: A Literature Review. International Journal of Research in English Education, 10-21.

Bezircilioğlu, S. (2016). Mobile Assisted Language Learning. Journal of Educational and Instructional Studies, 9-12.

Cakir, I. (2016). Current Trends in ELT. Cankaya, Ankara, Turkiye: Mustafa Kemal Mh.

Dashtestani, R. (2013). Implementing mobile-assisted language learning (MALL) in an EFL context: Iranian EFL teachers' perspectives on challenges and affordances. JALT CALL Journal, 149168.

Fageeh, A. (2013). Effects of MALL Applications on Vocabulary Acquisition and Motivation. International Peer Reviewed Journal, 420-447.

Haris, M., Yunus, M., \& Badusah , J. (2017). The Effectiveness of Using Padlet in ESL Classroom. International Journal of Advance Research (IJAR), 783-788.

Hazaea, A., \& Alzubi, A. (2016). The Effectiveness of Using Mobile on EFL Learners' Reading Practices in Najran University. English Language Teaching.

Jabbour, K. (2014). An analysis of the effect of mobile learning on Lebanese higher education. Network of Scientific Journals from Latin America, 53-67.

Kaliisa, R., \& Picard, M. (2017). A Systematic Review on Mobile Learning in Higher Education: The African Perspective. The Turkish Online Journal of Educational Technology, 1-18.

Kavlu, A. (2015). The Place of Reading in EFL Context. International Journal of Social Sciences \& Educational Studies, 81-88.

Kealey, M. (2014). Mobile-Assisted Language Learning.

Khaki, N. (2014). Improving Reading Comprehension in a Foreign Language: Strategic Reader. The Reading Matrix, pp. 187-200.

Khubyari, L., \& Narafshan, M. (2016). A STUDY ON THE IMPACT OF MALL (MOBILE ASSISTED LANGUAGE LEARNING) ON EFL LEARNERS' READING COMPREHENSION. International Journal of English Language Teaching, 58-69.

Kim, H. (2014). Effects of Using Mobile Devices in Blended Learning for English Reading Comprehension. Multimedia-Assisted Language Learning, 64-85.

Liu, C., \& Long, F. (2014). The Discussion of Traditional Teaching and Multimedia Teaching Approach in College English Teaching. 31-33.

Manowong, S. (2017). Incorporating Online Tools to Promote English Reading for EFL Learners: an Action Reaserch Study. Pasaa Paritat Journal, 98-124.

Miller, A., Merrill, M., \& Shamatov, D. (2018). Effective Teaching Strategies: A Brief Overview. 38-52.

Miller, H., \& Cuevas, J. (2017). Mobile Learning and its Effects on Academic Achievement and Student Motivation in Middle Grades Students. International Journal for the Scholarship of Technology Enhanced Learning, 91-110.

Mutia, F., Syafar, A., \& Dewi, A. K. (2016). Applying read, encode, annonate and ponder (REAP) technique to develop reading comprehension of the grade $\mathrm{x}$ students. E-Journal of English Language Teaching Society (ELTS), 1-11. 
Naderi, S., \& Akrami, A. (2018). EFL Learners' Reading Comprehension Development Through MALL: Telegram Groups in Focus. International Journal of Instruction, 340-350.

Nurviyani, V. (2018). Fostering Colledge Students' Critical Reading Skill Through Padlet Application. Jurnal Pendidikan Bahasa dan Sastra, 66-74.

Putri, H., \& Umam, M. (2018). The Use of Padlet in EFL Classroom: A case study of PMPBI Students 2017 of State University of Jakarta. 101-104.

Sa'aleek, A. (2014). A Review of Emerging Technologies: Mobile Assisted Language Learning (MALL). Asian Journal of Education and e-Learning, 469-475.

Singh, A. (2014). Challenges and issues of generation Z. Journal of Business and Management, 59-63.

Singh, A., \& Dangmei, J. (2015). Understanding The Generation Z: The Future Workforce. South-Asian Journal of Multidisciplinary Studies, 1-5.

Siu, G., \& Zhou, L. (2017). A Case Study of Using Padlet to Capture Insights in Class. 38-43.

Sulisworo, D., \& Toifur, M. (2016). The Role of Mobile Learning on The Learning Environment Shifting at High School in Indonesia. Int. J. Mobile Learning and Organisation, 159-170.

Takaloo, N., \& Ahmadi, M. (2017). The Effect of Learners' Motivation on Their Reading Comprehension Skill: A Literature Review. International Journal of Research in English Education, 10-21.

Veluchamy, R., Bharadwaj, M., Vignesh, \& Sharma, G. (2016). Personal and Professional Attitudes of Generation Z Students. International Journal of Circuit Theory and Applications, 471-478.

Widiana, P., Santosa, M., \& Myartawan, I. (2018). Tenth Grade Students' Perception Toward Mobile Assisted Language Learning (MALL) in Learning English in Buleleng Regency in Academic Year2017/2018. Ejournal JPBI Universitas Pendidikan Ganesha. 